\title{
A strange deceit
}

\author{
David Stafford-Clark
}

"In cottage gardens sweet flowers drink Last dregs of colour from the fading light. Their scent floats on the dusk, to link With the now distant thunder of the engines In a strange deceit;

As if the world went well ..."

Two questions arise from this quotation: What is the nature of this strange deceit? and why is it still with us? (as it still is). The poem was written during 1943, and the author was a doctor whose duties included flying with bomber command of the Royal Air Force. It was in fact part of my increasing awareness of the inseparability of psychiatry from general medicine and of the understanding of morale and fear and guilt in the context of both.

But now, over 50 years later, 25 of them spent as a teacher and senior consultant in psychiatry at Guy's Hospital, I am left with a conviction that doctors are still uneasy in the way that they deal with death, common enough in their experience, but often shunned in their communication to the next of kin to whom they owe honest and lucid explanation and compassion as well as concern. I could give many examples of this but one will have to suffice.

The patient was a boy of eight, who had developed bone cancer in his left shin: a Ewing's sarcoma. Following confirmation of the clinical diagnosis by biopsy, he had his left leg amputated up to the lower third of his thigh. Even so the outlook was virtually hopeless but the correct procedure was to plan for his survival, including the fitting of an artificial limb. Meanwhile he was encouraged to regain mobility, first by crutches, and then after discarding them with a child's combination of impatience, natural poise and adaptability, to hop about the ward on one leg like a lively little bird. He did all this with tireless and supremely optimistic enthusiasm.

I was at that time engaged in researching the attitude of children to their disability, and to those responsible for their care, including their parents as well as doctors and nurses. A routine question concerned the child's plans for the future. "What do you plan to be when you grow up, Billy?" "I want to be a professional cricketer. I want to be one of the best." "A cricketer Billy, what about running?" "I'd aim to be a batsman. You see if I can hit enough boundaries running isn't going to bother me; I could always have someone else to run singles or twos or threes . . ." This encounter arose out of a research fellowship. It was no part of my job to demur at anything the children said but the doctors and nurses on Billy's ward were already firmly enrolled in his supporters' club for this impossible fantasy. It not only settled his attitude, but theirs too, for the remaining six months of his life. His parents were grateful for the sustenance which this fictional magical promise, and denial of inevitability of his death, gave them during his brief post-operative survival. But their gratitude did not survive the realisation, once he had died, that at no point during his post-operative course had anyone tackled, humbly but honestly, the admittedly terrible but inescapable duty of telling them the truth. Deprived of this essentially professional service, they had not only gone along with the merciful deception of their child, they too had allowed themselves to be deceived. For them, this deception had to be seen for what it was: a betrayal. At no stage had they been given the chance to come to terms with the heartbreaking reality - until it was too late.

There is nothing exceptional about this. The first simple and obvious answer to this in our profession is that we have a duty to be honest. lucid and compassionate in dealing with the hardest facts we may encounter, but it is also reasonable to ask what can be our motivation, apart from professional integrity. I submit that it has to be love of a dedicated and dispassionate kind for those for whom we care and particularly their next of kin. Both the Qur'an and the Bible stress the supremacy of love over fear and guilt. 
"There is no fear in love; but perfect love casteth out fear."

(First Epistle General of St John)

". . . For love is strong as death; jealousy

is cruel as the grave."

(Song of Solomon)

Apart from love, is anything stronger than fear or guilt in the human range of emotion? Certainly not hatred, jealousy or envy; all have firm roots in fear. The denial of fear, guilt or responsibility, without acknowledgement of the necessity of love, is the nature of the 'strange deceit'. If doctors, as responsible educated men and women, and particularly psychiatrists, who do understand something about fear, guilt and responsibility, are to be listened to they must first set their own house in order. Physicians as a whole can be complacently ignorant even about things which are within their total and immediate concern.

A leading article in the British Medical Journal (13 November 1982), dealt with the prolongation of dying when it is impossible to preserve life with any quality of awareness or participation. It was subtitled "Thou shalt not strive officiously". Its opening sentence read, "Most medical students encounter the dictum 'Thou shalt not strive officiously to keep alive' early in their clinical years."

I took the trouble to look it up in the Oxford Dictionary of Quotations. It is part of a poem by Arthur Hugh Clough (1819-1861) entitled The Latest Decalogue' and its first five couplets are as follows

"Thou shalt have one God only, who

Would be at the expense of two?

Thou shalt not kill; but needs't not strive

Officiously to keep alive.

Do not adultery commit:

Advantage rarely comes of it.

Thou shalt not steal; an empty feat.

When it's so lucrattve to cheat.

Thou shalt not covet; but tradition

Approves all forms of competition ...."
So not only is the article headed by a misinterpretation of the poem which heads it. but that poem has nothing to do with medical ethics or responsibility and proves to be a diatribe against current public and political hypocrisy on moral issues in the 19th century. To use the quotation in its incorrect context is evidence of a carelessness which doctors must avoid. But it would not be so well-enshrined in the tradition of medical teaching if the people who so readily use it had checked on its origin and meaning. This is simply an example of the responsibility which doctors must accept, to act and write and think and talk as educated people. Their even greater responsibility is to speak out clearly and unambiguously on all issues of humanity when they are asked.

So what is my final message? It is simply this: it may not be possible to develop or acknowledge perfect love in our hearts for every one of our fellow men and women but it is vital that we acknowledge that love and compassion must be part of medicine and that fear, ignorance, sloth, complacency or indifference are its worst enemies.

Confronted by a sick, frightened, disturbed, unhappy or even paranoid and threatening person, the doctor can remember this simple precept: "attention must finally be paid to such a person ... The phrase comes from Arthur Miller's play Death of a Salesman. Once patients realise that you care about how they feel, then you have given them a bridge to link their need to your capacity to help them. A bridge which they can cross to meet you and which you can cross to meet them. Good doctors have always recognised the necessity for such a bridge. And attention in the special context of the phrase I have quoted means not simply interest, not even simply compassion but the active, dedicated, detached, yet uncompromising love for other human beings which alone can inspire and ultimately crown the highest endeavours of medicine and of mankind.

David Stafford-Clark, retired; Consultant Emeritus, Guy's Hospital, London SE1 